University of Rhode Island

DigitalCommons@URI

The Rhode Island Current Conditions Index

Economics

$6-1-2020$

\title{
Rhode Island Current Conditions Index - June 2020
}

Leonard Lardaro

University of Rhode Island, lardaro@uri.edu

Follow this and additional works at: https://digitalcommons.uri.edu/ricci

Part of the Econometrics Commons

Terms of Use

All rights reserved under copyright.

\section{Recommended Citation}

Lardaro, Leonard, "Rhode Island Current Conditions Index -- June 2020" (2020). The Rhode Island Current Conditions Index. Paper 209.

https://digitalcommons.uri.edu/ricci/209

This Newsletter is brought to you for free and open access by the Economics at DigitalCommons@URI. It has been accepted for inclusion in The Rhode Island Current Conditions Index by an authorized administrator of DigitalCommons@URI.For more information, please contact digitalcommons-group@uri.edu. 


\title{
CURRENT CONDITIONS LEONARD LARDARO, URI
}

\author{
Available Online: http: / www.Ilardaro.com/current.htm \\ Twitter: @ladardo
}

VOL XXVIT

NUMBER 7 JUNE 2020

Rhode Island's economy continued to chug along further in June. While still saddled with highly depressed levels of economic activity, it continued to make further progress as more and more segments moved beyond recent shutdown levels. It bears further repeating that what we are witnessing is not a cyclical phenomenon by any means; it is the direct result of an exogenous shock that caused our state's economy to literally be shut down.

I remain convinced that barring some horrible acceleration in the COVID pandemic, even at this point, Rhode Island's economy has moved beyond what will prove to be the absolute bottom in its overall level of economic activity. That being said, because Rhode Island has never adequately adapted its economy to the realities of functioning as a successful post-manufacturing economy, it will very likely take three to five years before it returns to prepandemic levels of activity. If you have been following the progress of Rhode Island's economy, you are no doubt aware that even those levels weren't all that great, as our state's economy was already slowing prior to the pandemic (what would have proven to be the FI of FILO). While we have been spared the FI portion of FILO since every state went into this crisis simultaneously, the LO remains. At a time when we need to establish ourselves as a well defined post-manufacturing economy, we find ourselves in the unfortunate position of having our fate over the next several months largely out of our hands, directly tied to how well the COVID crisis is managed, national

\begin{tabular}{|l|r|}
\hline \multicolumn{2}{|c|}{ CCI Indicators - \% Change } \\
\hline Government Employment & -6.9 \\
\hline US Consumer Sentiment & -20.4 \\
\hline Single-Unit Permits & 15.1 \\
\hline Yetail Sales & -15.4 \\
\hline Employment Services Jobs & -30.5 \\
\hline Priv. Serv-Prod Employment & $-\mathbf{1 3 . 2}$ \\
\hline Total Manufacturing Hours & -6.6 \\
\hline Manufacturing Wage & 0.2 \\
\hline Labor Force & -0.9 \\
\hline Benefit Exhaustions & 152.4 \\
\hline New Claims & 331.9 \\
\hline Unemployment Rate (change) & $\mathbf{8 . 8}$ \\
\hline \multicolumn{2}{|c|}{ Y Improved Value } \\
\hline
\end{tabular}

fiscal policy and the ability of the Federal Reserve to sustain stability in financial markets. A crisis is a terrible thing to waste. The most pressing question is therefore whether Rhode Island will waste this crisis as it did the Great Recession.

So, what can be said about Rhode Island's economy in June? The good news is that the Current Conditions Index doubled from its May value, all the way to 17 , as two of the twelve indicators improved on a year-over-year basis. Single-Unit permits, which reflect new home construction, rose at a double-digit rate compared to last June $(+15.1 \%)$, moving above an annual rate of 1,000 units. Part of this move likely was the result of lower

\begin{tabular}{|c|c|c|c|c|c|}
\hline \multirow{4}{*}{7} & & Jan & Feb & Mar & Apr \\
\cline { 2 - 6 } & 2019 & $58 \downarrow$ & $50 \uparrow$ & 58 & $50 \downarrow$ \\
\cline { 2 - 6 } & 2020 & 75 & 75 & 33 & 8 \\
\hline
\end{tabular}

interest rates, an ironic by-product of this crisis. The other improving indicator, the Manufacturing Wage, has now improved for two consecutive months. While this might sound encouraging, it is not. I chose not to discuss this last month since

\begin{tabular}{|l|r|}
\hline CCI Indicators - Monthly\% Change \\
\hline Government Employment & -5.0 \\
\hline US Consumer Sentiment & 9.4 Y \\
\hline Single-Unit Permits & 50.5 \\
\hline Retail Sales & $\mathbf{8 . 4}$ \\
\hline Employment Services Jobs & $\mathbf{8 . 7}$ Y \\
\hline Priv. Serv-Prod Employment & $\mathbf{8 . 5}$ Y \\
\hline Total Manufacturing Hours & $\mathbf{8 . 6}$ \\
\hline Manufacturing Wage & -4.3 \\
\hline Labor Force & 5.2 \\
\hline Benefit Exhaustions & 40.7 \\
\hline New Claims & -49.5 Y \\
\hline Unemployment Rate (change) & $-4.0 ~ Y$ \\
\hline \multicolumn{2}{|c|}{ Y Improved Value } \\
\hline
\end{tabular}

I didn't want to "pile on" the bad news. The Manufacturing Wage, which is an average, rose because many of the jobs lost in June (and May) were lower paying service-sector jobs. When you eliminate large numbers of below-average values, the average necessarily rises, hardly a cause for celebration in this context.

As I did last month, I can report that the CCI based on monthly changes performed better than the yearly-based CCI. The monthly CCI (see above) was 50 in June, a neutral value, as half of the indicators improved relative to May. Keep in mind, we are comparing here to an economy close to a dead stop, which tends to make monthly changes large. However, month-over-month changes, if sustained, eventually determine how we are doing in terms of yearly comparisons. Let's hope the monthly progress, while hardly spectacular, is sustained in spite of the host of obstacles we face.

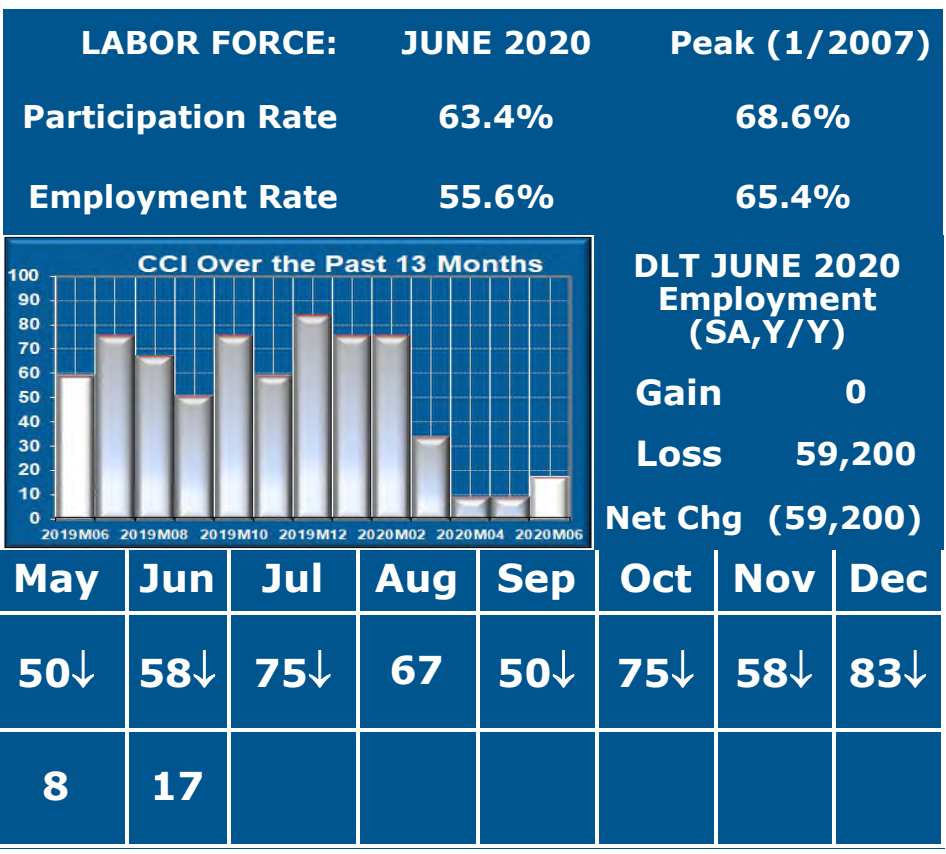

Gopyright (c 2018, 2019 Leonard Lardaro, Ph.D. All rights reserved. 